\title{
RAPID PREPARATION OF DIAGNOSTIC PROBES FOR THE FRAGILE X SYNDROME BY DIRECT PCR AMPLIFICATION OF HUMAN CHROMOSOMAL DNA
}

\author{
Masatake YAMAUCHI, Naohiko SEKI, and Tada-aki HoRI \\ Division of Genetics, National Institute of Radiological Sciences, \\ Anagawa, Inage-ku, Chiba 263, Japan
}

\begin{abstract}
Summary The fragile $\mathrm{X}$ syndrome is a common familial form of mental retardation and is associated with a rare fragile site at Xq27.3 (FRAXA). This disorder has recently been reported to correlate with length variations of restriction genomic DNA fragments which may due to the amplification of $(\mathrm{CCG})_{n}$ trinucleotide repeats located at the FRAXA locus. We described here a rapid preparation method of diagnostic DNA probes for the fragile $X$ syndrome by direct enzymatic amplification of human chromosomal DNA. The Pst I-assay, which is Southern blot analysis of DNA samples probed by PCR products, was shown to be sensitive method for diagnostic purposes to detect the size variations specific in the fragile $\mathrm{X}$ syndrome.
\end{abstract}

Key Words fragile X, polymerase chain reaction (PCR), DNA diagnosis

\section{INTRODUCTION}

The fragile $X$ syndrome is one of the most common genetic disorders with an incidence of 1 in 1,500 males (Sutherland and Hecht, 1985). This syndrome segregates dominantly in X-linked manner with reduced penetrance since both sex carrying this mutation may exhibit mental retardation. The syndrome has been shown to associate with a cytogenetic marker, a folate-sensitive fragile site located at Xq27.3, which is expressed under the conditions of thymidylate stress (Sutherland and Hecht, 1985; Hori et al., 1988). Identification of the cytogenetic carrier, however, was usually difficult for the following complications of the syndrome: (1) Majority of males carrying the fragile $\mathrm{X}$ mutation exhibits both clinical manifestations and cytogenetic expression of $\mathrm{fra}(\mathrm{X})(\mathrm{q} 27.3)$, but $20 \%$ of males with mutation do not express the fragile site and are phenotypically normal (so-called normal

Received May 11, 1992; Accepted June 22, 1992. 
transmitting males). The normal transmitting males transmit the mutation to their daughters and have fully affected grandsons. (2) While two thirds of female heterozygotes are phenotypically unaffected and also FRAXA expression is not observed, remaining one third of female carriers are intellectually impaired with FRAXA expression.

Recently the nature of the fragile $X$ mutation has been uncovered at molecular level. Kremer et al. (1991) reported that the characteristic trinucleotide repeat, $(\mathrm{CCG})_{n}$, was found in the restriction fragment where break point of the fragile site may lay. The size of the restriction fragments were increased in DNA samples derived from the fragile $X$ patients when subjected to Southern blot analysis. This suggested amplification of the $(C C G)_{n}$ repeat in the fragile $X$ patients may be responsible both in the increase of the restriction fragment and in the fragility of this particular locus.

Polymerase chain reaction (PCR) is one of the most convenient procedure to prepare DNA probes for screening and/or diagnosis as well as for direct detection of mutations in target genes, but specific amplification of the fragile $\mathrm{X}$ locus across (CCG) $)_{\mathrm{a}}$ repeat has not been successful (our unpublished observation).

In the present study we tried to prepare diagnostic DNA probes by direct enzymatic amplification of the human chromosomal DNA, and established the reproducible condition for direct PCR of both flanking region of the $(\mathrm{CCG})_{\mathrm{n}}$ repeat in the fragile $X$ locus. The PCR products were further used to screen the partiallydigested human genomic DNA library, and two overlapping clones were isolated and shown to be originated from Xq27.3 by in situ hybridization. We also describe here that the Southern blot analysis of the DNA samples probed by PCR products (Pst I-assay) can detect restriction fragment length variations between normal, heterozygous carrier, and patient affected by the fragile $\mathrm{X}$ syndrome.

\section{MATERIALS AND METHODS}

Polymerase chain reaction (PCR). We used two sets of oligonucleotide primers to amplify each adjacent part to the $(C C G)_{n}$ repeat as shown in Fig. 1. The nucleotide sequences of the primers were as follows:

FX-F1: 5'-CTGCAGAAATGGGCGTTCTGGC-3'

FX-F2: 5'-GTGTCACCGCCCTTCAGCCTTC-3'

FX-F3: 5'-CACCTCTCGGGGGCGGGCTCCC-3'

FX-F4: 5'-CGCTAGCAGGGCTGAAGAGAAG-3'

FX-R1: 5'-CTGCAGGAGGTGGCCCGGCTGA-3'

FX-R2: 5'-CAACTACCCACACGACAGGCCC-3'

FX-R3: 5'-CGGAAGTGAAACGAAACGGAGC-3'

FX-R4: 5'-CGGCCCGCCGCCCGCTCAGAGA-3'

The chromosomal DNA samples were extracted by the standard procedure. PCR was performed in a reaction mixture $(50 \mu \mathrm{l})$ containing $67 \mathrm{~mm}$ Tris- $\mathrm{HCl}(\mathrm{pH} 8.8)$, 
$17 \mathrm{~mm}$ ammonium sulfate, $2 \mathrm{~mm}$ magnesium chloride, $0.45 \%$ Triton $X-100,0.2$ $\mathrm{mg} / \mathrm{ml}$ gelatin, $1 \mu \mathrm{g}$ of chromosomal DNA, and $6 \mathrm{ng}$ each of appropriate oligo primers as recommended by the manufacturer (Biotech International Ltd., Australia). PCR was performed reciprocally between $95^{\circ} \mathrm{C}$ and $72^{\circ} \mathrm{C}$, for $1 \mathrm{~min}$ each, by 30 cycles without typical annealing step. For colony PCR each small portion of colonies of transformants was directly put into reaction mixture, and the reactions were carried out using universal primers, M4 and RV (Takara, Ohtsu, Japan) by the standard condition $\left(93^{\circ} \mathrm{C}, 1 \mathrm{~min} \rightarrow 60^{\circ} \mathrm{C}, 1 \mathrm{~min} \rightarrow 72^{\circ} \mathrm{C}, 1 \mathrm{~min}, 30\right.$ cycles). All polymerase chain reactions were carried out in the DNA Thermal Cycler (Perkin Elmer Cetus, USA).

Analysis of the PCR products. The secondary PCR products were digested by appropriate restriction endonucleases (Fig. 1) and were subcloned into pUC119 plasmid vector. White colonies were selected on X-gal plates containing ampicillin, and the sizes of inserts were examined by colony PCR technique as described above.

$D N A$ samples of fragile $X$ patients. Total genomic DNA was extracted from human lymphoblastoid cell lines and somatic cell hybrids. The lymphoblastoid cell lines established from male patients with the fragile X syndrome (FX132, 135, 137, and 310) were provided by I. Kondo (Ehime Univ.). The FX312 was from an affected female heterozygote who expressed fra(X)(q27.3) and FX311 was from normal male in the same family of FX310 (Arinami et al, 1987). A cell line FX86-111, from a fragile $X$ male patient was provided by T. Kajii (Yamaguchi Univ.). Somatic hybrid cell lines retaining a human fragile $\mathrm{X}$ chromosome were established by cell fusions between mouse cells and skin fibroblasts of fragile $\mathrm{X}$ male patients: TS/86, FSthy21 and 86-111; 13H5, tsFT20 and RS4729 (Hori et al., 1988). The other cell lines for controls were developed by K. Yamamoto and T. Ikeuchi (Tokyo Med. Dent. Univ.), and by T. Hashimoto (Hyogo Med. Univ.) by EBV-transformation of peripheral blood lymphocytes from carriers of autosomal rare fragile sites (D3, B3, HeD5, L-177-1, L-118, L-118-1, and L-118-2), and from patients affected by ataxia telangiectasia (ATMO, ATFU, and AT53), respectively. The HeD5, L-118, ATMO, and AT53 were derived from females and all the others were from males.

Southern blot hybridization. Restriction digests of DNA samples were subjected to $1 \%$ agarose gel electrophoresis, and were alkali-transferred to a nylon membrane filter (Zetaprobe, BioRad, USA). Hybridization was performed by the standard condition in $3 \times \mathrm{SSC}-50 \%$ formamide containing salmon sperm DNA, Denhaldt's solution and dextran sulfate at $42^{\circ} \mathrm{C}$ overnight. Filters were washed in $0.1 \times \mathrm{SSC}$ $0.1 \% \mathrm{SDS}$ at $60^{\circ} \mathrm{C}$ twice, and then autoradiographed.

\section{RESULTS AND DISCUSSION}

\section{Polymerase chain reaction}

For direct and specific amplification of DNA fragments from the fragile $X$ 
region using human chromosomal DNA as a template, we set oligonucleotide primers as described in the Materials AND Methods and Fig. 1. In our preliminary experiments the standard condition $\left(\right.$ i.e. $93^{\circ} \mathrm{C}, 1 \mathrm{~min}-60^{\circ} \mathrm{C}, 1 \mathrm{~min}-72^{\circ} \mathrm{C}, 1 \mathrm{~min}$, 30 cycles) was employed for PCR step cycle, and those experiments resulted in having very high backgrounds even when nested oligos were used in the secondary PCR, perhaps because of unusually high GC content around the region. Then we started to manipulate the reaction condition, changing the concentrations of salts, of dNTPs and of magnesium as well as temperatures in the step cycle. We also examined several sources of Taq DNA polymerases from different manufacturers. We finally found out that the combination with the reaction composition and Taq DNA polymerase from Biotech using reciprocal cycle for PCR as described in MATERIALS AND METHODS has given the most consistent results both in yield and in specificity of the amplification.

Although little specific PCR products were amplified after primary amplification using various combinations of oligo-primers (lanes 1-6 in Fig. 2), it appeared to have specific products after secondary PCR using nested-oligos. Especially when PCR was performed using the primer combination, F3+R1, and then using $\mathrm{F} 4+\mathrm{R} 2$, the specific DNA fragment of $0.5 \mathrm{~kb}$ was observed most reproducibly (lane 10). Using $\mathrm{F} 2+\mathrm{R} 4$ as nested-oligos after the first PCR using F1+R3 also gave successful results, but the specificity of the resultant product was a little lower than using $\mathrm{F} 3+\mathrm{R} 1 \rightarrow \mathrm{F} 4+\mathrm{R} 2$ (lane 9). It is noteworthy that specific products can be seen on the lanes 7 and 8 after the second PCR, suggesting enzymatic amplification has occurred across the $(\mathrm{CCG})_{\mathrm{n}}$ repeat using oligo-primers, $\mathrm{F} 1+\mathrm{R} 1$, though the yields of PCR products had been significantly lower. DNA fragments which seemed to be the same sizes as specific products were sometimes observed after primary amplification using $\mathrm{F} 2+\mathrm{R} 4$ and $\mathrm{F} 4+\mathrm{R} 2$, but the results were not always successful after multiple repeats of the same experiments. Digestion of chromosomal DNA by $P_{s t}$ p prior to PCR did not make any differences both in yield and in specificity of the amplification.

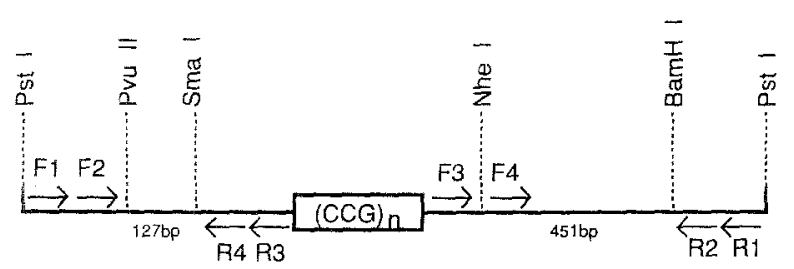

Fig. 1. Alignment of oligo-nucleotide primers and restriction sites around the (CCG $)_{n}$ repeat. Each adjacent part to the trinucleotide repeat was primarily amplified using either $F 1+R 3$ or $F 3+R 1$. Primary PCR products were then amplified again using nested-oligos, F2+R4 and F4 $+\mathrm{R} 2$, respectively. Resultant PCR products were subcloned into pUC119 plasmid vector at appropriate restriction sites for further analyses. 


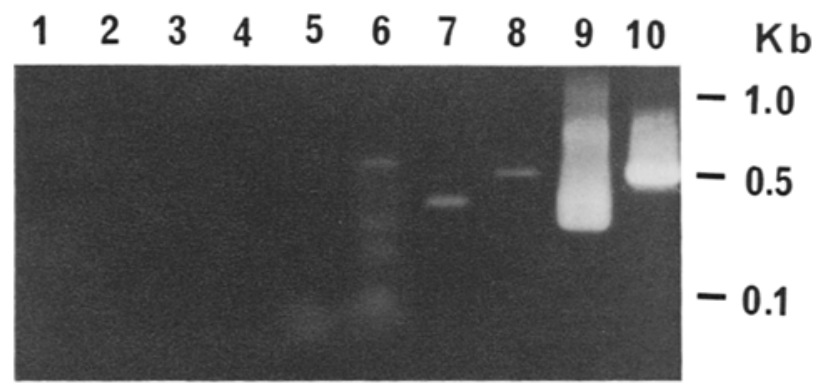

Fig. 2. Ethidium bromide staining of the PCR products. PCR products were subjected to $1 \%$ agarose gel electrophoresis and were stained by ethidium bromide. Product sizes here are slightly larger than those represented in Fig. 1 because the products were not digested by restriction endonucleases yet. Primer combinations employed for each lane was as follows:

\begin{tabular}{crc}
\hline Lane & Primary PCR & Secondary PCR \\
1 & F1+R1 & - \\
2 & F2 +R2 & - \\
3 & F2+R4 & - \\
4 & F4+R2 & - \\
5 & F1+R3 & - \\
6 & F3 $+\mathrm{R} 1$ & $\mathrm{~F} 2+\mathrm{R} 4$ \\
7 & $\mathrm{~F} 1+\mathrm{R} 1$ & $\mathrm{~F} 4+\mathrm{R} 2$ \\
8 & $\mathrm{~F} 1+\mathrm{R} 1$ & $\mathrm{~F} 2+\mathrm{R} 4$ \\
9 & $\mathrm{~F} 1+\mathrm{R} 3$ & $\mathrm{~F} 4+\mathrm{R} 2$ \\
\hline
\end{tabular}

\section{Isolation of genomic DNA clones}

PCR products were then subjected to appropriate restriction digestions and DNA fragments were subcloned into pCU119 plasmid vector. Genomic clones were screened from the partially-digested human genomic DNA libraries as described previously (Yamauchi et al., 1990, 1991) for the PCR products were not long enough for in situ hybridization. Several clones were identified and two of them appeared to cover up to $20 \mathrm{~kb}$ around the (CCG) $)_{n}$ repeat as shown in Fig. 3. Our restriction map of the clones coincided to the ones which have been constructed on the DNA fragments derived from yeast artificial chromosome (YAC) clones spanning the fragile $\mathrm{X}$ breakpoint (Verkerk et al., 1991; Yu et al., 1991; Kremer et al., 1991). The chromosomal location of the genomic clones isolated here were further confirmed by fiuorescence in situ hybridization to localize at the expressed site of the fragile $\mathrm{X}$ chromosome (data not shown). This suggests that the PCR products amplified and subcloned here were highly specific and could be used as diagnostic probes for the fragile $\mathrm{X}$ syndrome. 


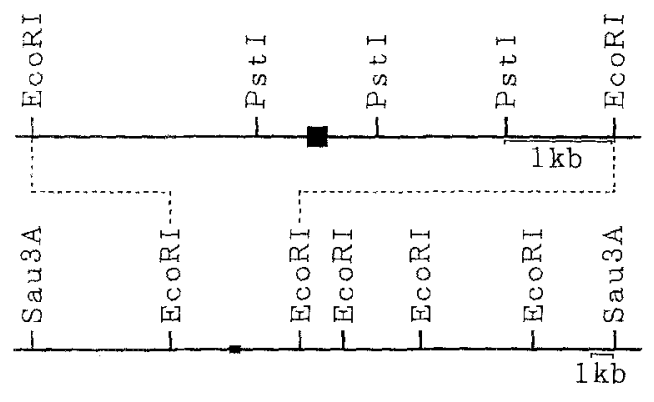

$\lambda$ 进 111

Fig. 3. Human partially-digested genomic DNA clones covering the fragile $X$ region. Solid box represents the $(\mathrm{CCG})_{n}$ repeat. PCR products which were derived from the $P_{s t} \mathrm{I}$ fragment containing $(\mathrm{CCG})_{\mathbf{n}}$ repeat were used as probes. Several clones were identified from the library and two of them (bottom solid lines) appeared to overlap, covering about $20 \mathrm{~kb}$ around the $(\mathrm{CCG})_{\mathfrak{n}}$ repeat. The two genomic clones were further confirmed to derive from the fragile site by in situ hybridization technique.

\section{Southern blot analysis}

To examine if the PCR products subcloned here could be applicable for diagnostic purpose using Southern blot hybridization technique, we employed DNA samples from various sources including the fragile $X$ syndrome male patients, a female carrier, somatic cell hybrids between skin fibroblasts from fragile $X$ male patients and cultured mouse cell lines, and normal individuals. Typical results of Southern blot analysis on EcoRI-digested and Pst I-digested DNA samples are shown in Fig. $4 \mathrm{a}$ and $4 \mathrm{~b}$, respectively. A $5 \mathrm{~kb}-E c o$ RI fragment and a $1 \mathrm{~kb}-P s t \mathrm{I}$ fragment were detected from both normal controls and an affected female (FX312) using radio-labeled $0.5 \mathrm{~kb} P C R$ product. FX311 was a fragile $X$-negative male, and showed normal size of the restriction fragment. These results were consistent with the ones reported by other groups (Verkerk et al., 1991; Yu et al., 1991; Kremer et al., 1991), and any size variations in the restriction fragments were not observed among normal DNA samples in our assay conditions.

In contrast, significant alterations were observed in the mobilities of restriction fragments from both the fragile $X$ patients and the hybrid cells (Fig. 4). In case of the EcoRI-digested samples the size of restriction fragments were increased up to $8 \mathrm{~kb}$ (Fig. 4a). These size variations can be detected more clearly in the Pst I-digested samples, where the sizes were varying from $1.5 \mathrm{~kb}$ to $4.0 \mathrm{~kb}$ comparing to the normal size of $1.0 \mathrm{~kb}$ (Fig. 4b). The differences in the size of restriction fragments $(0.5-3.0 \mathrm{~kb})$ were consistent between the EcoRI-digested samples and the Pstl-digested ones. This suggests that the size variation should be due to the changes occurred within $1 \mathrm{~kb}-P s t \mathrm{I}$ fragments.

To explain the molecular basis of these size variations, the simplest explanation 

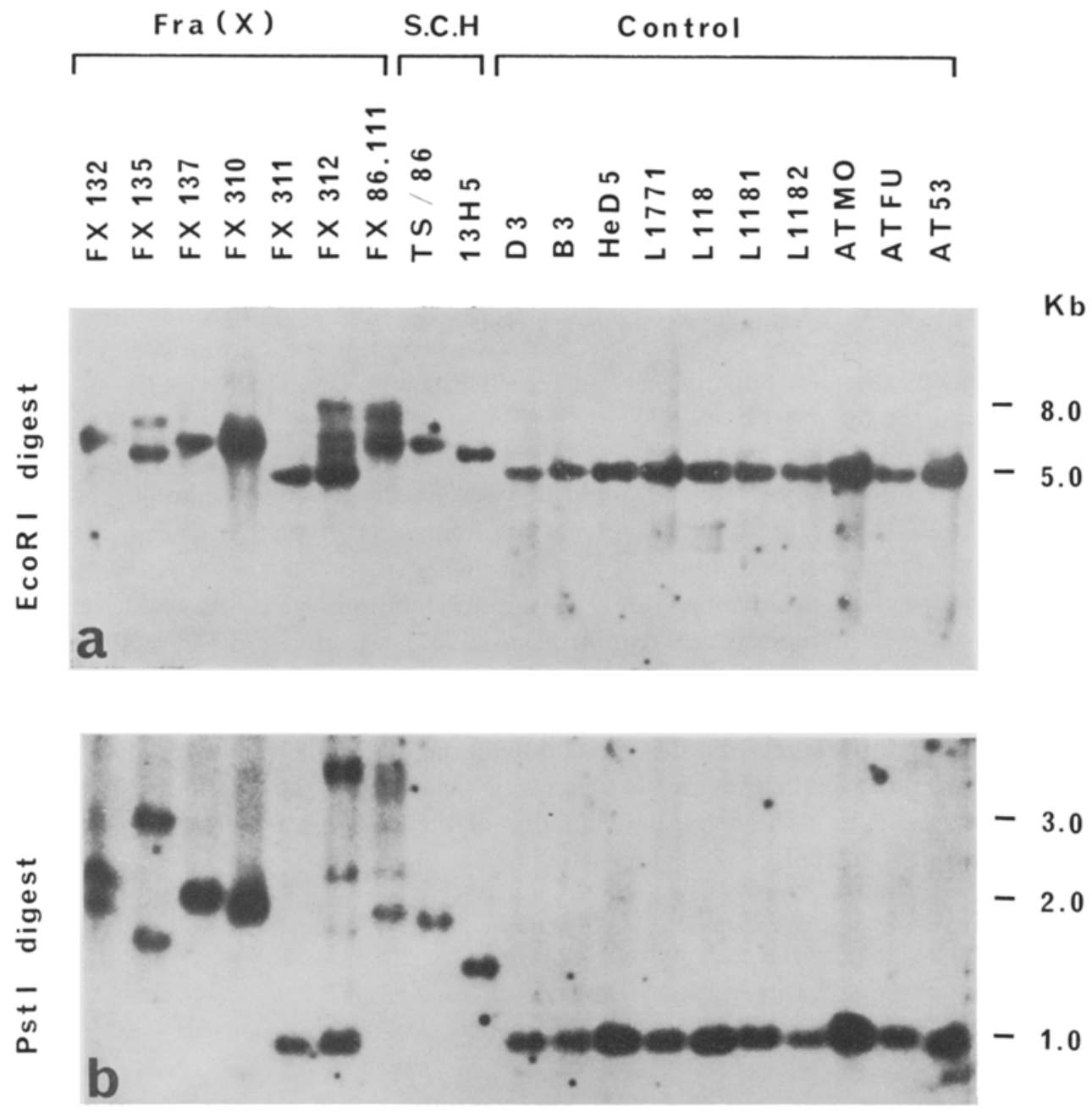

Fig. 4. Southern blot analysis of DNA samples from various sources. Details of DNA samples and conditions are described in the Materials and Methods. 5.0 $\mathrm{kb}-E c o \mathrm{RI}$ fragment and $1.0 \mathrm{~kb}-P_{s t} \mathrm{I}$ fragment were detected from the normal control samples. The sizes of these restriction fragments were increased in the samples derived from fragile $\mathrm{X}$ individuals as well as in the ones from somatic cell hybrids (abbreviated as S.C.H.). Note that FX311 is a normal male in the same family of FX310.

would be increased copy number of the (CCG) $)_{\mathbf{n}}$ repeat. Kremer et al. (1991) reported when they have analyzed the copy number of the $(\mathrm{CCG})_{n}$ repeat in a hybrid cells derived from a fragile X-expressing male, the repeat length have fallen within the normal range of 43 copies in a genomic DNA clone isolated from the hybrid cells while the size of restriction fragment containing the $(C C G)_{n}$ repeat have sig- 
nificantly aitered in the original affected male patient. This suggests the DNA fragment containing the $(\mathrm{CCG})_{n}$ repeat is unstable during cloning process.

Another characteristic aspect of the altered restriction fragments detected in the fragile $X$ patients was that some of them have shown length variation of these fragments. This suggests that a chromosomal region containing (CCG) r repeat seemed not to be maintained stably even in a single individual. The somatic variations observed in the affected patients might be the consequence of unequal sister chromatid exchange after DNA replication of the mutated $X$ chromosome. In addition we observed in our preliminary experiments on fragile $X$ families that the size of Pst I-fragments were increased when the mutant chromosomes were transmitted by females, but not were increased when transmitted by males as previously reported by Yu et al. (1991).

In conclusion, the DNA probes described here, which were directly amplified from chromosomal DNA, can be applicable for diagnostic purpose to detect the length variations in the fragile X-expressing individuals. But we need further experiments for carrier detection and prenatal diagnosis for the fragile $X$ syndrome since some fragile X-positive individuals without exhibition of any detectable length variation have been reported (Nakahori et al., 1991). In our another preliminary experiment we have been accumulating consistent observations in detecting the transcript of FMR gene, which is expressed from fragile $X$ region, using RT-PCR technique (Pieretti et al., 1991). The combination of Southern blot analysis and RT-PCR would raise the accuracy of diagnostic detection of the fragile $X$ syndrome to satisfactory level. The definitive diagnosis of the fragile $\mathrm{X}$ syndrome by molecular basis will soon replace the cytogenetic one.

Acknowledgments We thank to Dr. I. Kondo and Dr. T. Kajii for providing cell lines derived from fragile $\mathrm{X}$ patients.

\section{REFERENCES}

Arinami T, Kondo I, Hamaguch $H$, Tamura K, Hirano T (1987): A fragile X female with Down syndrome. Hum Genet $77: 92-94$

Hori $T$, Takahashi E, Tsuji H, Tsuji S, Murata M (1988): Fragile X expression in thymidine-prototrophic and auxotrophic human-mouse somatic cell hybrids under low and high thymidylate stress conditions. Cytogenet Cell Genet 47: 177-180

Kremer EJ, Pritchard M, Lynch M, Yu S, Holman K, Baker E, Warren ST, Schlessinger D, Sutherland GR, Richards RI (1991): Mapping of DNA instability at the fragile X to a trinucleotide repeat sequence $p(C C G)_{n}$. Science $252: 1711-1714$

Nakahori Y, Knight SJ, Holland J, Schwartz C, Roche A, Tarleton J, Wong S, Flint TJ, Froster IU, Bentley D, Davies KE, Hirst MC (1991): Molecular heterogeneity of the fragile X syndrome. Nucieic Acid Res 19:4355-4359

Pieretti M, Zhang F, Fu Y, Warren ST, Oostra BA, Caskey CT, Nelson DL (1991): Absence of expression of the FMR-1 gene in tragile X syndrome. Cell 66: $817-822$

Sutherland GR, Hecht F (1985): Fragile sites on human chromosomes. Oxford ,University Press, New York, Oxford 
Verkerk A JMH, Pieretti M, Sutcliffe JS, Fu Y, Kuhl DPA, Pizzuti A, Reiner O, Richards S, Victoria MF, Zhang F, Eussen BE, van Ommen GB, Blonden LAJ, Riggins GJ, Chastain JL, Kunst CB, Galjaard H, Caskey CT, Nelson DL, Oostra BA, Warren ST (1991): Identification of a gene (FMR-1) containing a CGG repeat coincident with a breakpoint cluster region exhibiting length variation in fragile X syndrome. Cell 65: 905-914

Yamauchi M, Yamauchi N, Meuth M (1990): Molecular cloning of the human CTP synthetase gene by functional complementation with purified human metaphase chromosomes. EMBO J 9: 2095-2099

Yamauchi M, Yamauchi N, Phear G, Spurr NK, Martinsson T, Weith A, Meuth M (1991): Genomic organization and chromosomal localization of the human CTP synthetase gene. Genomics 11: 1088-1096

Yu S, Pritchard M, Kremer E, Lynch M, Nancarrow J, Baker E, Holman K, Mulley JC, Warren ST, Schlessinger D, Sutherland GR, Richards RI (1991): Fragile X genotype characterized by an unstable region of DNA. Science 252: 1179-1181 